\title{
Speed loss analysis during Illinois agility run test in light
} of some Bio-kinematics parameters

\section{"Dr /Hani Abdol Aziz Saleh}

Research Problem:

Agility has been defined as the ability to maintain a controlled body position and rapidly change direction without a loss of balance, body control, or speed. (7), (8)

The components of agility have been defined as balance, coordination, power, and speed. (2), (4)

There are two components forming physical abilities, physical fitness and motor fitness. Physical fitness consists of muscular strength, muscular endurance of respiratory-circulatory, and flexibility. While motor fitness components are built by motion, speed, coordination, agility, and balance. (10), (12)

Biomechanics provides information for a variety of kinesiology professions to analyze human movement to improve effectiveness or decrease the risk of injury. How the movement is analyzed falls on a continuum between a

qualitative analysis and a quantitative analysis. Quantitative analysis involves the measurement of biomechanical variables and usually requires a computer to do the voluminous numerical calculations performed. Even short movements will have thousands of samples of data to be collected, scaled, and numerically processed. In contrast, qualitative analysis has been defined as the "systematic observation and introspective judgment of the quality of human movement for the purpose of providing the most appropriate intervention to improve performance" (5), (6)

The time variable is the main indicator of agility. When the test time is reduced, it is an indicator of the agility component of the laboratory, and the longer the test time, the less the athlete or the

${ }^{*}$ Lecturer in Sport Training and Movement Science Department, Faculty of Physical Education for (Men - Girls) in Port-Said, Port-Said University, A.R.E Associate professor at Faculty of education - Physical Education \& Movement Science Department, Al Qassem University, K.S.A

Assiut Journal For Sport Science Arts 
laboratory is lacking the fitness component.

The importance of this study is to identify the moments in which a player's loss speed and thus an increase in the performance time of the test, which can be determined by identifying and analyzing the reasons for lack of the player to the element of fitness and how to overcome the loss speed at those stages and thus increase the element of fitness.

And then put some of the suggested exercises it can reduce the loss speed, which in turn increase the players agility.

\section{Illinois agility run test:}

Purpose: to test running agility Equipment required: flat non-slip surface, marking cones, stopwatch, measuring tape, timing gates (optional)

Procedure: The length of the course is 10 meters and the width (distance between the start and finish points) is 5 meters. Four cones are used to mark the start, finish and the two turning points. Another four cones are placed down the center an equal distance apart. Each cone in the center is spaced 3.3 meters apart. Subjects should lie on their front (head to the start line) and hands by their shoulders. On the 'Go' command the stopwatch is started, and the athlete gets up as quickly as possible and runs around the course in the direction indicated, without knocking the cones over, to the finish line, at which the timing is stopped.

\section{Results:}

An excellent score is under 15.2 seconds for a male, less than 17 seconds for a female. See the full rating norm scores for the Illinois Test.

\section{Advantages:}

This is a simple test to administer, requiring little equipment. Also, the player's ability to turn in different directions and different angles is tested.

\section{Disadvantages:}

Choice of footwear and surface of area can effect times greatly. Results can be subject to timing inconsistencies, which may be overcome by using timing gates. Cannot distinguish between left and right turning ability.

Variations: the starting and finishing sides can be swapped, so that turning direction is reversed.

\section{Table (1)}




\section{Illinoi`s Agility Test Evaluation}

\begin{tabular}{c|c|c|c}
\hline \hline valuation & degree & women & men \\
\hline \hline Excellent & 5 & $<17.0 \mathrm{~s}$ & $<15.2 \mathrm{~s}$ \\
\hline Above Average & 4 & $17.0-17.9 \mathrm{~s}$ & $15.2-16.1 \mathrm{~s}$ \\
\hline Average & 6 & $18.0-21.7 \mathrm{~s}$ & $16.2-18.1 \mathrm{~s}$ \\
\hline Below Average & 2 & $21.8-23.0 \mathrm{~s}$ & $18.2-19.3 \mathrm{~s}$ \\
\hline Poor & 1 & $>23.0 \mathrm{~s}$ & $>19.3$ \\
\hline \hline
\end{tabular}

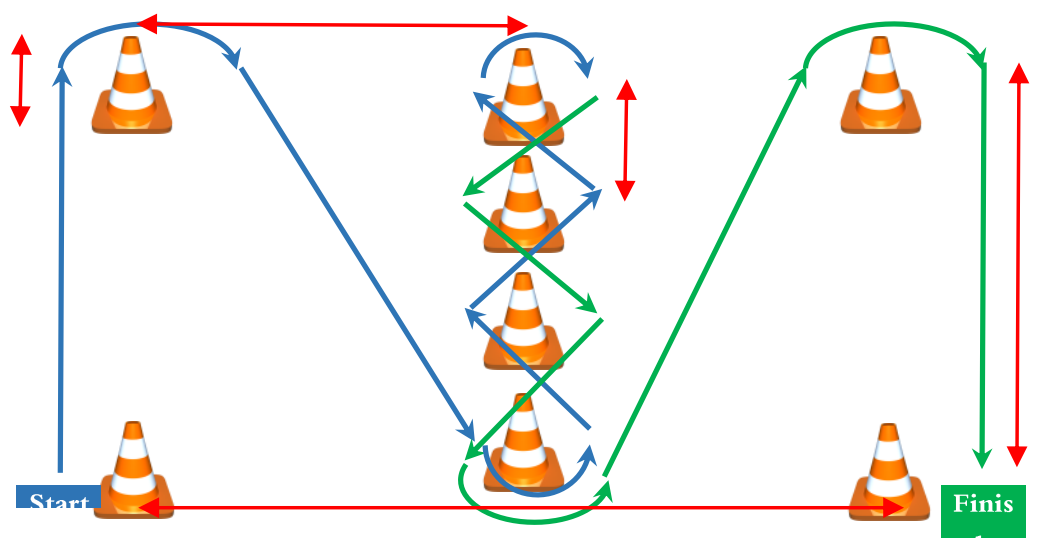

Figure (1) Illinoi`s Agility Running Test

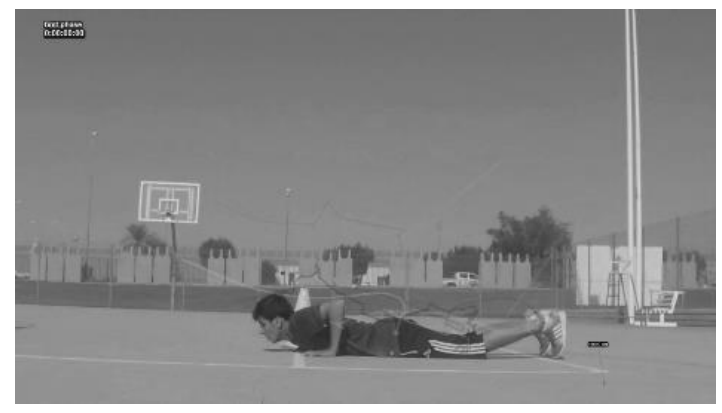

Figure (2) Illinoi`s Agility Running Test Start Position (Putting down)

The Researcher studied 1- Standing from start Illinoi`s Agility Test phases as Position: this phase including follows: tow Sub-stages:

a- First Sub-stage: this phase starts from start signal 
from Putting down (figure (2)) and ends at Balling Position and four limps touching the ground. Figure (3)

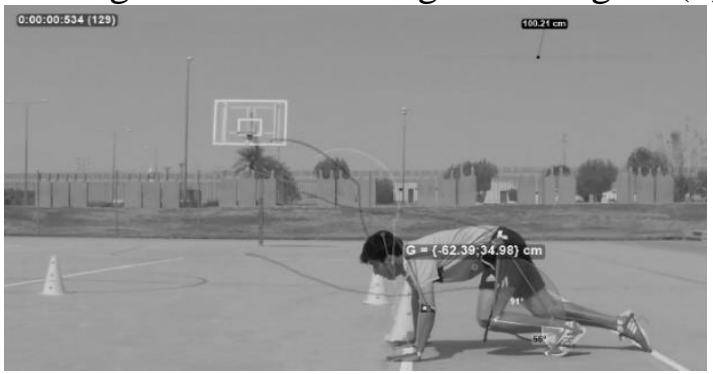

Figure (3) First Sub-Phase from first phase (Balling)

b- Second Sub-stage: this Position and ends at Running phase starts from Balling Position. Figure (4)

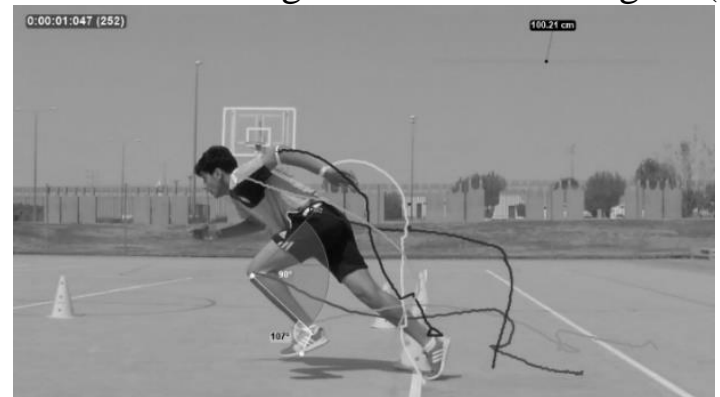

\section{Figure (4) Second Sub-Phase from first phase (Running)}

2- Circulation around the a- First Sub-stage: this cones Phase: this phase phase starts from Approaching including tow Sub-stages: and ends at beginning circulation. Figure (5)

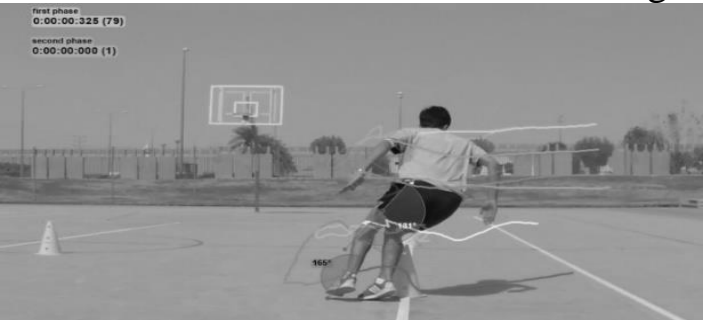

Figure (5) First Sub-Phase from second phase (Approaching)

b- Second Sub-stage: this phase starts from finishing circulation and ends at Run Starting. Figure (6) 


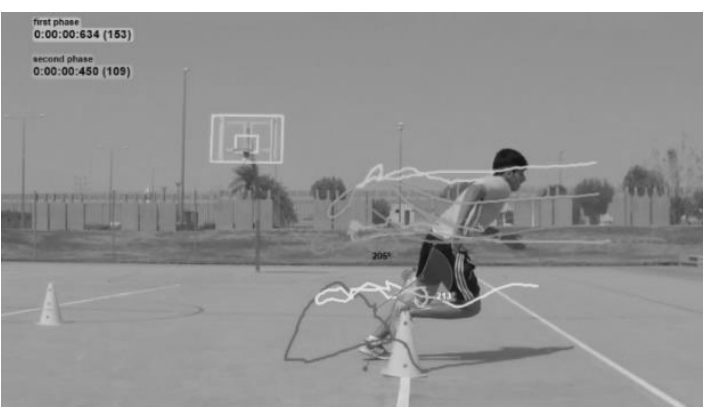

Figure (6) second Sub-Phase from second phase (Run Starting) 2/0 Research Aims:

This research aims to:

2/1 Illinoi`s agility Running test time analysis.

2/2 Illinoi`s agility Running test speed loss analysis.

2/3 Design suggested exercises it can reduce the loss speed.

3/0 Research Qustions:

3/1 what is Illinoi`s agility Running test time analysis?

3/1 what is Illinoi`s agility Running test speed loss analysis?.

4/0 Research Symbols:

\begin{tabular}{c|c|l}
\hline \hline measurement & symbol & \multicolumn{1}{|c}{ Term } \\
\hline \hline $\mathrm{Sec}$ & $\mathrm{t}$ & Time \\
\hline $\mathrm{Cm}$ & $\mathrm{Dx}$ & Horizontal displacement Component \\
\hline $\mathrm{Cm}$ & $\mathrm{Dy}$ & Vertical displacement Component \\
\hline $\mathrm{Cm} / \mathrm{sec}$ & $\mathrm{Vx}$ & Horizontal Velocity \\
\hline $\mathrm{Cm} / \mathrm{sec}$ & $\mathrm{Vy}$ & Vertical Velocity \\
\hline $\mathrm{Cm} / \mathrm{sec}$ & $\mathrm{Vr}$ & Resultant Velocity \\
\hline \hline
\end{tabular}

5/0 Research Methodology:

The researcher used the descriptive method by using Kinematical analysis, as this is more suitable for the nature of the research

\section{6/0 Research Simple:}

The sample was selected from Physical Education and Kinesiology Department - Al Qassim University, The sample of the research (10) all of them did the test three times

Table (2)

Research Simple Description 




\begin{tabular}{c|c|c|c}
\hline \hline & measure & Mean & S.D \\
\hline \hline Tall & $\mathrm{Cm}$ & 177 & 4.35 \\
\hline Age & Year & 21 & 1.00 \\
\hline Wight & $\mathrm{Kg}$ & 66.83 & 4.36 \\
\hline Illinoi`s test time & $\mathrm{Sec}$ & 17.37 & 0.936 \\
\hline Illinoi`s test Degree & degree & 3 & 0.00 \\
\hline \hline
\end{tabular}

7/0 Anthropometric Data collection tools

7/1 Biomechanics Data collection tools

Capture, 2D Video: By Gopro hero4 black Camera (240fbs)



\section{Figure (7) Gopro hero4 black}

\section{7/2 Biomechanics analysis by} "Kinonea" software:

The researcher used "Kinonea" for kinematics analysis of running to four points represent three segments (Upper arm fore arm - hand - thigh - leg -

Table (3)

Illinoi`s agility Running test time analysis

\begin{tabular}{c|c|c}
\hline \multirow{2}{*}{ Illinoi`s agility Running test Phases } & \multicolumn{2}{|c}{ Illinois agility Running test Phases } \\
\cline { 2 - 3 } & $\mathbf{\%}$ & Sec \\
\hline \hline Total test time average & 17.46 & $100 \%$ \\
\hline Standing from Putting down to running to con 2 & 2.65 & $15 \%$ \\
\hline Circulation and running to con 3 & 2.86 & $16 \%$ \\
\hline Circulation and first zigzag & 3.28 & $19 \%$ \\
\hline Circulation and second zigzag & 2.88 & $17 \%$ \\
\hline Circulation and running to con 7 & 3.02 & $17 \%$ \\
\hline Circulation and running to finish line & 2.77 & $16 \%$ \\
\hline \hline
\end{tabular}

foot) in two axes (horizontal $x$, vertical y) to get Kinematical variables in four phases.

\section{8/0 Results:}

8/1 Illinoi`s agility Running test time analysis:

$$
\text { - thigh - leg - }
$$




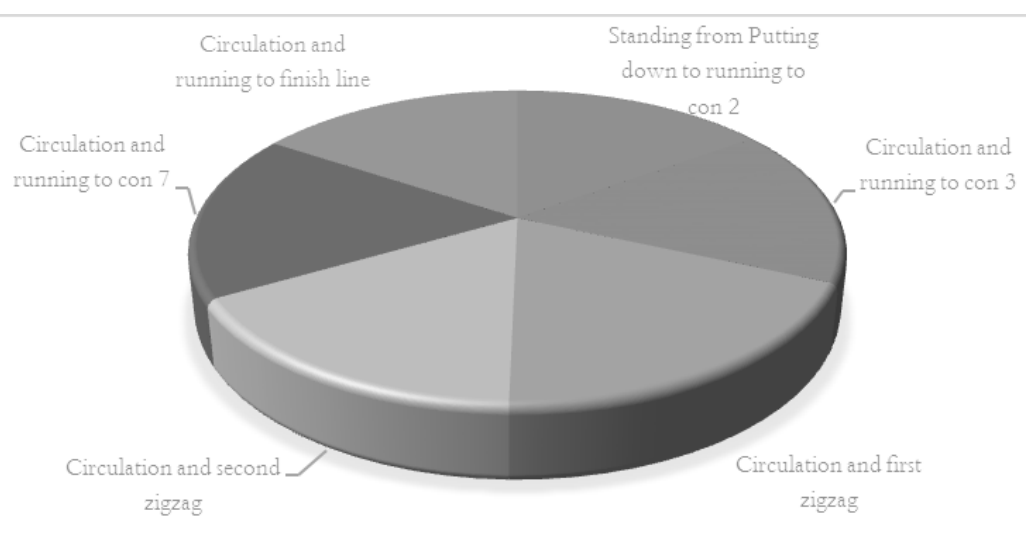

Figure (8) Illinoi`s agility Running test time analysis

Table (4)

Illinoi`s agility Running test major Phases time analysis

\begin{tabular}{c|c|c|c}
\hline \hline \multirow{2}{*}{ Major Phases } & \multirow{2}{*}{ Sub-Phases } & \multicolumn{2}{|c}{ time analysis } \\
\cline { 3 - 4 } & & Sec & \% \\
\hline \hline \multirow{2}{*}{ Standing } & Balling & 2.17 & $51 \%$ \\
\cline { 2 - 4 } & Running & 2.12 & $49 \%$ \\
\hline \multirow{2}{*}{ Circulation } & Approaching & 2.59 & $54 \%$ \\
\cline { 2 - 4 } & Run Starting & 2.21 & $46 \%$ \\
\hline \hline
\end{tabular}

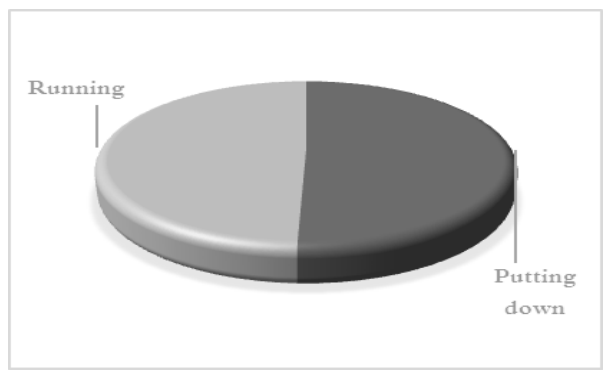

Standing

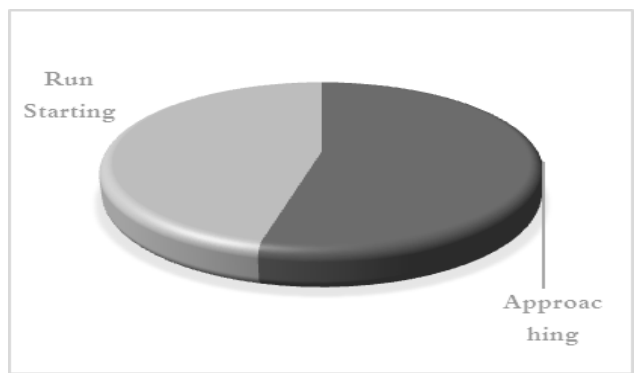

irculation

Figure (9) Illinoi`s agility Running test major Phases time analysis 
666

8/2 Present the results of Illinoi’s agility Running test kinematical analysis:

8/2/1 Standing Phase:

Table (5)

Illinoi`s agility Running test kinematical analysis (Standing Phase)

\begin{tabular}{|c|c|c|c|c|c|c|c|c|}
\hline \multirow{2}{*}{ Segment } & \multirow{2}{*}{ Phase } & $\mathbf{T}$ & $\bar{X}$ & $\bar{Y}$ & $\overline{\bar{D}}$ & $\mathbf{V x}$ & $\overline{\mathrm{Vy}}$ & $\overline{\mathrm{V}}$ \\
\hline & & sec & $\mathrm{cm}$ & $\mathrm{cm}$ & $\mathrm{cm}$ & $\mathrm{Cm} / \mathrm{s}$ & $\mathrm{Cm} / \mathrm{s}$ & $\mathrm{Cm} / \mathrm{s}$ \\
\hline \multirow{2}{*}{$\begin{array}{l}\text { Center } \\
\text { of Mass }\end{array}$} & Ballmng & 2.17 & -28.59 & $\begin{array}{l}-18.36 \\
\end{array}$ & 33.9 & -13.16 & -8.46 & 15.65 \\
\hline & Running & 2.12 & -136.1 & 47.88 & 144.2 & 64.19 & -22.85 & 68.05 \\
\hline \multirow{2}{*}{$\begin{array}{l}\text { Upper } \\
\text { arm }\end{array}$} & Balling & 2.17 & 109.1 & 28.6 & 32.3 & 0.70 & 0.38 & 1.19 \\
\hline & Running & 2.12 & 85.1 & 55.13 & 11.7 & 0.55 & 0.41 & 2.17 \\
\hline \multirow{2}{*}{ Fore arm } & Balling & 2.17 & -79.2 & 18.46 & 25.04 & 0.57 & -0.204 & 0.831 \\
\hline & Running & 2.12 & -71.28 & 43.99 & -.15 & 0.755 & 1.05 & 2.47 \\
\hline \multirow{2}{*}{ Hand } & Balling & 2.17 & -101.42 & -2.78 & 21.75 & 0.495 & -0.208 & 0.721 \\
\hline & Running & 2.12 & -61.8 & 28.181 & -.49 & 1.23 & 1.316 & 2.842 \\
\hline \multirow{2}{*}{ Thigh } & Balling & 2.17 & -66.65 & 23.27 & 36.35 & 0.616 & 0.658 & 1.42 \\
\hline & Running & 2.12 & -45.36 & 48.195 & 121.76 & 0.414 & -0.013 & 2.08 \\
\hline \multirow{2}{*}{ Leg } & Balling & 2.17 & -43.45 & 4.21 & 33.70 & -0.67 & -0.015 & 1.52 \\
\hline & Running & 2.12 & -41.58 & 11.68 & 120.03 & -0.029 & 0.148 & 1.70 \\
\hline \multirow{2}{*}{ Foot } & Balling & 2.17 & 15.38 & 14.44 & 10.179 & -0.197 & -0.255 & 1.733 \\
\hline & Running & 2.12 & -12.17 & 4.86 & 116.89 & -0.215 & 0.520 & 1.167 \\
\hline
\end{tabular}

8/2/1 Circulation Phase:

Table (6)

Illinoi`s agility Running test kinematical analysis (Circulation

Phase)

\begin{tabular}{|c|c|c|c|c|c|c|c|c|}
\hline \multirow[t]{2}{*}{ Segment } & \multirow[t]{2}{*}{ Phase } & $\mathbf{T}$ & $\bar{X}$ & $\overline{Y Y}$ & D & $\bar{V} \mathbf{V x}$ & $\overline{V y}$ & $\overline{\mathrm{V}}$ \\
\hline & & sec & $\mathbf{c m}$ & $\mathbf{c m}$ & $\mathbf{c m}$ & $\mathrm{Cm} / \mathrm{s}$ & $\mathrm{Cm} / \mathrm{s}$ & $\mathrm{Cm} / \mathrm{s}$ \\
\hline \multirow{2}{*}{$\begin{array}{l}\text { Center } \\
\text { of Mass }\end{array}$} & $\overline{\text { Appl }}$ & 2.59 & 121.72 & 2.49 & 121.74 & 46.99 & 0.761 & 448.0 \\
\hline & Run Star & 2.21 & 4 & -7 & 03 & 18.28 & 3.425 & 18.59 \\
\hline \multirow{2}{*}{$\begin{array}{l}\text { Upper } \\
\text { arm }\end{array}$} & $\mathrm{Ap}$ & 2.59 & 2 & 8 & 4 & 24 & 1.89 & 1.829 \\
\hline & Run Starting & 2.21 & 152.12 & 119.52 & 177.82 & 1.524 & 0.022 & 1.785 \\
\hline \multirow{2}{*}{ Fore arm } & Appi & 2.59 & -155.14 & 105.5 & 103.7 & -2.147 & -0.122 & 2.611 \\
\hline & Run Starting & 2.21 & -164.6 & 104.78 & 205.55 & 1.77 & -0.066 & 2.18 \\
\hline
\end{tabular}


Follow Table (6)

Illinoi 's agility Running test kinematical analysis (Circulation Phase)

\begin{tabular}{|c|c|c|c|c|c|c|c|c|}
\hline \multirow[t]{2}{*}{ Segment } & \multirow[t]{2}{*}{ Phase } & $\bar{T}$ & $\bar{X}$ & $\overline{\mathbf{Y}}$ & $\overline{\mathbf{D}}$ & $\mathbf{V x}$ & $\overline{V y}$ & $\overline{\mathbf{V}}$ \\
\hline & & sec & cm & cm & cm & $\mathrm{Cm} / \mathrm{s}$ & $\mathrm{Cm} / \mathrm{s}$ & $\mathrm{Cm} / \mathrm{s}$ \\
\hline \multirow[t]{2}{*}{ Hand } & App & 2.59 & $\begin{array}{c}- \\
167.09\end{array}$ & 85.53 & 101.77 & 1.649 & 0.095 & 2.832 \\
\hline & Run Starting & 2.21 & -1.559 & 89.00 & 261.4 & 1.816 & 0.222 & 3.439 \\
\hline \multirow{2}{*}{ Thigh } & Approaching & 2.59 & -143.8 & 85.20 & 96.85 & -2.20 & 0.165 & 2.389 \\
\hline & Run Starting & 2.21 & -167.2 & 91.05 & 185.83 & 1.192 & 0.025 & 1.564 \\
\hline \multirow{2}{*}{ Leg } & Approaching & 2.59 & -169.7 & 53.56 & 89.03 & -1.80 & 0.032 & 2.20 \\
\hline & Run Starting & 2.21 & $\begin{array}{c}- \\
163.86\end{array}$ & 52.99 & 192.3 & 1.052 & 0.009 & 1.653 \\
\hline \multirow{2}{*}{ Foot } & Approaching & 2.59 & $\begin{array}{c}- \\
197.99\end{array}$ & 20.54 & 120.75 & $\begin{array}{c}- \\
2.375\end{array}$ & 0.135 & 2.926 \\
\hline & Run Starting & 2.21 & $\begin{array}{c}- \\
184.62\end{array}$ & 39.92 & 244.3 & 0.960 & $\begin{array}{c}- \\
0.007\end{array}$ & 1.754 \\
\hline
\end{tabular}

Discussion

discusses the result of the first question "what is Illinoi's agility Running test time analysis?"

Seen from table (5) the time of Illinoi`s agility Running test was (17.46 sec) that from test start to the end of test, the plyer get score (3) according to table (1). And that shows the players has average level in agility.

The researcher attributes that to the player didn't get enough agility training, and this is consistent with $\mathrm{M}$, Allawy \& M, Naser (1994) the agility doesn't has enough attention from trainers in sports field at generally.(5)

Which consistent with Amiri Khorarani, Et.al (2010) and M., Tabrizi Et.al (2010) Although that Agility is important in improving the player's physical level and his contribution to helping the player's body perform the required motor duty, it does not occupy that space during sports training. (9), (13).

As seen from table (6) the Circulation around con with zigzag running was the biggest phase in time, the researcher see that this phase including Approaching to the 
con and Circulation around con thin running in maximum velocity.

The researcher attributes that to in this phase the body decrease velocity during Approaching to the con, and this is a prelude to the Circulation around con, which loses the body a large part of its velocity and thus spend more time.

Jamal al-Din (1994) \& M, Allawy (1989) explains that mechanical variables effects each on other and that the study of all the biomechanical parameters surrounding the performance is the key to obtaining logical explanations of motion. (6) (7)

The researcher attributes that to the mechanical variables surrounding the body of velocity, acceleration, force and impulse and moment of momentum, help maintain the body's position in motion forward, in accordance with Newton's first law (inertial law).

So if the player tries to change his position during the run, by circulating around cons it requires the player to resist those mechanical variables and adapted to achieve the goal of movement, which forces the player to reduce the velocity to change the direction of the body.

Which consistent with Raya, M. Et.al (2013) and Tarik Huremovic, Et.al (2009) Vescovi, J. Et.al (2008) That zigzag running or circular running around the axis leads to the loss of the moment of momentum because of the rotational velocity acquired during this type of running, And also because of the speed that is moving and acting as a repulsive force must be resisted by the player so as not to disturb body equilibrium.

As shown in Table (5) that the least time-consuming is to stand up from Putting, The researcher attributes that to the velocity of reaction taken by the player immediately after the launch of the start signal to reduce the time taken at this phase, and this phase requires only two stages:

- Balling.

- Running.

This has led to the reduction of time at this phase significantly and make it the least phase of time lagging, where the body at this phase to push the ground with maximum force and rush forward in order to get the right 
situation for the launch and running

As shown in Table (3) and Figure (8) that Illinoi`s Agility Running test phases takes between 15\% - 19\% which are close ratios.

The researcher attributes this to the test designer has taken care of the division of times almost equally during the test performance phases, so that the test is objective and honest to adopt the test.

Which consistent with M, Allawy \& M, Naser (1994) that the design of physical tests must be based on scientific basic, and the test must be of honesty, objectivity and consistency so that researchers and trainers can depend on it on the results of those tests

As shown in Table (6) the velocity increased during the Running phase more than Balling phase, where the total velocity reached $15.6 \mathrm{~m} / \mathrm{s}$ in Balling phase and then multiplied reaching $68.05 \mathrm{~m} / \mathrm{s}$ in running phase.

The researcher attributes this to that the Balling phase takes the most time of the phases of standing from Putting, because it depends on pushing the ground with hands and feet by great force to try to get the body to stand in the least time to start running.

Which consistent with M., Tabrizi Et.al (2010) and Usama-Alvarez Et.al (2010) That Illinoi`s Agility Running test is the only fitness test in which body shape changes between Putting, Balling and running. Therefore, this test should be used for its features in changing the shape of the body and body mass location. (13) (18)

Thus, the answer to the first question of the study achieved a "what is Illinoi's agility Running test time analysis?"

- discusses the result of the second question "what is Illinoi's agility Running test speed loss analysis?"

- Illinoi`s agility Running test speed loss analysis (Standing Phase)

Seen from table (6) that the Speed loss shows at horizontal velocity to upper arm, leg and thigh, and Resultant Velocity of foot.

The researcher attributes this to that the upper arm stops moving during the body transform from Balling to Running. As soon as the hands push the ground, the movement 
transform from the arms to the legs to stand and run.

The leg also has a large vertical velocity because the leg and the thigh are in the starting position and are attached to the ground. And the shape of the body changes from the Putting position to Balling. Thus, the movement on the vertical axis is more than the horizontal axis. So thigh and leg have Vertical velocity, although decrease on the horizontal axis, which caused the loss of horizontal velocity of the thigh and leg.

While the researcher see that there is a speed loss in the Resultant of velocity of the foot because the foot during this phase stop moving and act as a force by the contraction of the muscles of the toes to push the body up and forward to transform from Putting to the Running, The instantaneous foot caused the loss of speed to it.

\section{- Illinoi's agility Running test speed loss analysis (Circulation Phase):}

Seen from table (6) that speed loss during Circulation Phase in:

- Horizontal, vertical and resultant velocity of thigh, leg and foot.
- Horizontal, vertical and resultant velocity of upper arm and fore arm.

- Horizontal and resultant velocity of center of mass.

The researcher attributes this to that that as the player approaches to con, the player reduces his velocity to get rid of the moment of momentum which acquired during the run.

As the velocity decreases, the player can change his position and turn around the con, because the moment of momentum works pushing the body forward, and with the player trying to spin, the Accelerating speed increases that can cause the player loss his balance.

So the player must get rid of the moment of momentum before starting to turn around the con, which increased the loss of speed, and thus increase the time period of the Circulation around the con.

Which consistent with Ahmed Mahmoud (1994), and Ahmed Bayoumy (2014) That the speed loss occurs when the player focus in the place of his foot and this reduces the speed because of the player's attention to place the foot more than the speed of approaching 
and the achievement of the required motor duty.

In addition, the player circulation around the con at the lowest possible angle so as not to be far from the center of the circle of repression, which facilitates the rotation of the rotation of the body, This also requires the player to reduce his speed in the approaching and circulation around the con, so that the torque can't increase the circumference of the circulation circle in which the body running.

Thus, the answer to the first question of the study achieved a "what is Illinoi's agility Running test speed loss analysis?"

\section{conclusions}

and

recommendations:

Conclusions

Within the limits of the research objectives, the research questions and the results the researchers concluded the following :

- $\quad$ Illinoi`s Agility running test time mean is (17.00sec).

- Illinoi`s Agility running test is the most test which the body changes his pattern from Putting to Balling to running to Zigzag Running.
- $\quad$ Speed Loss happened at Circulation around the con.

- $\quad$ Speed Loss happened at transformation from Putting to Balling.

- $\quad$ Speed Loss happened at transformation from Balling to Running.

\section{recommendations:}

In light of the outcome of the results of the study, the researcher to formulate recommendations of the study are as follows:

- Using Illinoi`s Agility running test enhancing agility.

- $\quad$ Reducing and shrink the running step in approaching phase leads to body controlling be easier without speed loss.

- Increasing the foot frequency in the approaching phase to leads to save earned velocity.

- Increasing the foot frequency in the approaching phase fit with to foot frequency, leads to save earned velocity.

- Closing Center of mass to the ground via bending the knee at approaching phase and Circulation around the con phase guaranteed body equilibrium and stability.

- Using suggested exercises can reduce the loss speed. table (7) 
Table (7)

some of the exercises suggested to reduce the loss of speed during

the performance of the Illinois Agility running test

\begin{tabular}{|c|c|c|c|}
\hline & $\begin{array}{c}\text { Test } \\
\text { Phases }\end{array}$ & $\begin{array}{c}\text { Speed Loos } \\
\text { Phases }\end{array}$ & The suggested exercises \\
\hline 1 & Standing & Balling & $\begin{array}{l}\text { (Lying with arms in front of the chest) } \\
\text { extending the arms forward } \\
\text { (Lying with arms in front of the chest) } \\
\text { push the arms forward } \\
\text { (Oblique slant) involving the knees to } \\
\text { the chest } \\
\text { (Oblique slant) Insert the knees to the } \\
\text { chest and then jump up } \\
\text { (The oblique slant on the fingers of } \\
\text { the hand) joined the knees to the chest }\end{array}$ \\
\hline 2 & & Running & $\begin{array}{c}\text { Running from low start } \\
\text { Running out of lying position } \\
\text { Running from oblique position } \\
\text { Running from the position of } \\
\text { stagnation }\end{array}$ \\
\hline 3 & & Approaching & $\begin{array}{l}\text { Quick run in place } \\
\text { Quick run in place and then start } \\
\text { ahead at full speed } \\
\text { Quick run forward and then run in } \\
\text { place at full speed }\end{array}$ \\
\hline 4 & Circulation & Run Starting & $\begin{array}{l}\text { Running and circling around the back } \\
\text { cones } \\
\text { Running and circling twice about } \\
\text { repression } \\
\text { Run down and roll around the half- } \\
\text { roll funnel then back down }\end{array}$ \\
\hline
\end{tabular}

\section{References:}

Arabic references:

1- Ahmed Bayoumi Shafei: biomechanical variables and (2014) "The impact of the use long jump distance", of qualitative exercises to unpublished doctoral thesis, reduce loss of speed on some Faculty of Physical Education 
Boys - Girls Port Said, University of Port Said.

2- Ahmed Saad Eddin

Mahmoud:

(1994)

"Improvement of the loss of speed of approach and its impact on some of the variables Kinematik long distance jump," unpublished doctoral thesis, Faculty of Physical Education Boys, Alexandria University.

3- Ahmed Kassri Maani, Mohamed Sobhi Hassanein: (1988) "Encyclopedia of Applied Sports Training", book center for publishing, Cairo.

4- Ahmed Mohamed Khater: (1984) "Measurement in the field of sports," I 3, Dar Maaref, Alexandria.

\section{5- Ehab Adel Abdul-Basir,} Adel Abdul Basir Ali: (2005) "Biochemical analysis and integration between theory and practice in the field of sports," United Printing and Photography, Port Said.

6- Gamal Mohamed Alaa EI Din: (1994) "Laboratory Studies in Biomechanics of Mathematical Movements", 3, Dar Al Ma'aref, Alexandria.
7- Mohammed

Hassan

Allawi: (1989) "tests of motor performance," I 2, Dar Al-Fikr Al-Arabi, Cairo.

8- Mohamed Hassan Allawi, Mohamed Nasr El-Din Radwan: (1994) "Measurement in Physical Education and Mathematical Psychology, II, Dar Al-Fikr Al-Arabiya, Cairo English references:

9- Amiri-Khorasani, M., Sahebozamani, RoopchandMartin, S., \& Lue-Chin, P. (2010). Plyometric training improves power and agility in jamaica's national netball team. The West Indian Medical Journal, 59(2), 182.

10- Edwards, S., Austin, A. P., \& Bird, S. P. (2017). The role of the trunk control in athletic performance of a reactive change-of-direction task. Journal of Strength and Conditioning Research, 31(1), 126-139.

doi:10.1519/JSC.00000000000 01488

11- Hachana, Y., Chaabène, H., Nabli, M. A., Attia, A., Moualhi, J., Farhat, N., \& Elloumi, M. (2013). Test- 
retest reliability, criterionrelated validity, and minimal detectable change of the Illinois agility test in male team sport athletes. Journal of Strength and Conditioning Research, 27(10), 2752-2759. doi:10.1519/JSC.0b013e31828 $90 \mathrm{ac} 3$

12- Lockie, R. G., Schultz, A. B., Callaghan, S. J., Jeffriess, M. D., \& Berry, S. P. (2013). Reliability and validity of a new test of change-of-direction speed for field-based sports: The change-of-direction and acceleration test (CODAT). Journal of Sports Science \& Medicine, 12(1), 8896.

13- M., Tabrizi, K. G., \& Yusof, A. B. (2010). Acute effect of different stretching methods on Illinois agility test in soccer players. Journal of Strength and Conditioning Research, 24(10), 2698-2704. doi:10.1519/JSC.0b013e3181b f049c

14- Mohammed Nawi Alanazi Homoud (2015). Relationships Between Illinois Agility Test And Reaction
Time In Male Athletes, the Swedish Journal of Scientific Research ISSN: 20019211.Vol. 2. Issue 3. March. 2015

15- Negra, Y., Chaabene, H., Hammami, M., Amara, S., Sammoud, S., Mkaouer, B., \& Hachana, Y. (2017). Agility in young athletes: Is it a different ability from speed and power? Journal of Strength and Conditioning Research, 31(3), 727-735.

doi:10.1519/JSC.00000000000 01543

16- Raya, M. A., Gailey, R. S., Gaunaurd, I. A., Jayne, D. M., Campbell, S. M., Gagne, E., Tucker, C. (2013). Comparison of three agility tests with male servicemembers: Edgren side step test, T-test, and illinois agility test. Journal of Rehabilitation Research and Development, 50(7), 951-960. doi:10.1682/JRRD.2012.05.00 96

17- Tarik Huremovic, Alija biberovic, Haris Pokskic (2009) "Predictive Value Of Kinematic Parameters On The Assiut Journal For Sport Science Arts 
Results Of The Long Jump With Students, International Journal of Kinesiology, Volume 6 - Issue 2 - pp 19:24 18- Usma-Alvarez, C. C., Chua, J. J. C., Fuss, F. K., Subic, A., \& Burton, M. (2010). Advanced performance analysis of the Illinois agility test based on the tangential velocity and turning radius in wheelchair athletes. Sports

Technology, 3(3), 204-214. doi:10.1080/19346182.2011.56 4284

19- Vescovi, J. D., \& McGuigan, M. R. (2008). Relationships between sprinting, agility, and jump ability in female athletes. Journal of Sports

Sciences, 26(1), 97-107.

doi:10.1080/026404107013486 44

\section{Internet references:}

20- http://www.topendsports.c om/testing/tests/illinois.htm 21- https://filacrosse.com/wp content/themes/ sportedge /downloads /FIL_Referee_ Fitness_ Testing _Protocol_2014.pdf

22- https://www.brianmac.co.u k/illinois.htm

23- https://en.wikipedia.org/wi ki/Illinois_agility_test 24- http://www.elitesoccercon ditioning.com/Testing/Illinoisa gilitytest.htm 